\title{
Mutualistic Growth of the Sulfate-Reducer Desulfovibrio vulgaris Hildenborough with Different Carbohydrates ${ }^{1}$
}

\author{
M. M. Santana ${ }^{a, 2}$, M. C. Portillo ${ }^{b}$, and J. M. Gonzalez ${ }^{b}$ \\ a Instituto de Ciências Agrárias e Ambientais Mediterrânicas (ICAAM), \\ Departamento de Fitotecnia, Laboratório de Virologia Vegetal, Universidade de Évora, \\ Núcleo da Mitra, Évora, 7002-774 Portugal \\ ${ }^{b}$ Institute de Recursos Naturales y Agrobiología, Av. Reina Mercedes, 10, Sevilla, E-41012 Spain
}

Received November 16, 2011

\begin{abstract}
Desulfovibrio vulgaris Hildenborough genome presents a phosphotransferase system putatively involved in the transport of carbohydrates. However, utilization of sugars by this sulfate-reducing bacterium has never been reported. Herein, we have observed proliferation of $D$. vulgaris Hildenborough with some carbohydrates, in mutualism with Stenotrophomonas maltophilia, a non-fermentative, gram-negative gammaproteobacterium, or Microbacterium, a gram-positive actinobacterium. These results suggest the importance of feedback interactions between different heterotrophic bacterial species including the alternative for D. vulgaris of exploiting additional organic resources and novel habitats. Thus, D. vulgaris strongly participates in the mineralization of carbohydrates both in complex natural and artificial systems.
\end{abstract}

Keywords: mutualism, Desulfovibrio vulgaris Hildenborough, Stenotrophomonas maltophilia, Microbacterium sp.

DOI: $10.1134 / \mathrm{S} 002626171206015 \mathrm{X}$

Desulfovibrio vulgaris subspecies vulgaris strain Hildenborough, a member of the delta subdivision of the Proteobacteria group, is a typical example of sulfate-reducing bacteria, i.e., it uses sulfate as terminal electron acceptor for the heterotrophic oxidation of a few organic compounds including lactate, pyruvate, formate, and some primary alcohols [1]. Hydrogen increases the growth yield on lactate and growth on acetate plus $\mathrm{CO}_{2}$, with $\mathrm{H}_{2}$ as sole energy source, is also possible [2]. D. vulgaris Hildenborough fermented pyruvate in the absence of sulfate [3]. Due to the presence of an incomplete tricarboxylic acid cycle [4] carbon sources are generally oxidized down to acetate [5]. To date, utilization of sugars by $D$. vulgaris Hildenborough has not been reported. Utilization of carbohydrates has been reported for Desulfovibrio fructosovorans [6], D. zosterae [7] and D. cavernae [8].

The putative phosphotransferase system (PTS) genes present in $D$. vulgaris Hildenborough genome [9] have been scarcely studied. Sequence homology analysis suggests that $D$. vulgaris Hildenborough could potentially transport PTS-sugars of the mannose family [10]. The additional presence in $D$. vulgaris Hildenborough of genes encoding enzymes of the EmbdenMeyerhof-Parnas pathway [9, 10], the degradation pathway of PTS-transported sugars, indicates that mannose class sugars may be degraded by this pathway

\footnotetext{
${ }_{2}^{1}$ The article is published in the original.

${ }^{2}$ Corresponding author; e-mail: msantana@uevora.pt
}

to pyruvate, producing ATP by substrate level phosphorylation [10]. D. vulgaris is a common member of diverse microbial communities from soils [11] and a variety of environments and actively participates in the complex process of organic matter degradation. PTStransported sugars are common carbohydrates likely to be found in natural habitats where $D$. vulgaris has been detected [12].

In order to define conditions for potential growth of $D$. vulgaris Hildenborough on several carbon sources, including several mannose-PTS sugars, this strain's growth was examined under different conditions including interactions with other bacteria.

\section{MATERIALS AND METHODS}

Growth conditions. A volume of $100 \mu \mathrm{L}$ of a Desulfovibrio vulgaris Hildenborough culture in exponential phase of growth (OD at $600 \mathrm{~nm} \mathrm{0.37),} \mathrm{measured} \mathrm{with}$ a Hitachi U-180 spectrophotometer, was inoculated on modified A1 medium [13] plates with the following composition per liter: $2 \mathrm{~g} \mathrm{NH}_{4} \mathrm{Cl}, 2 \mathrm{~g} \mathrm{MgSO}_{4} \cdot 7 \mathrm{H}_{2} \mathrm{O}, 0.5 \mathrm{~g}$ $\mathrm{K}_{2} \mathrm{HPO}_{4}, 0.035 \mathrm{~g} \mathrm{CaCl}_{2} \cdot 2 \mathrm{H}_{2} \mathrm{O}, 0.005 \mathrm{~g} \mathrm{FeSO}_{4} \cdot 7 \mathrm{H}_{2} \mathrm{O}$, $0.125 \mathrm{~g}$ L-cysteine hydrochloride, $0.1 \mathrm{~g}$ of yeast extract and $0.002 \mathrm{~g}$ EDTA. The $\mathrm{pH}$ was adjusted to 7.5 by addition of $\mathrm{NaOH}$ and $15 \mathrm{~g} / \mathrm{L}$ bacto-agar were added. After autoclaving, $1 \mathrm{~mL}$ of an anoxic supplement solution (per liter: $2 \mathrm{~g} \mathrm{CaCO}_{3}, 6 \mathrm{~g}$ iron(III) citrate, $1.44 \mathrm{~g}$ $\mathrm{ZnSO}_{4} \cdot 7 \mathrm{H}_{2} \mathrm{O}, 0.9 \mathrm{~g} \mathrm{CoSO}_{4} \cdot 7 \mathrm{H}_{2} \mathrm{O}, 0.06 \mathrm{~g} \mathrm{H}_{3} \mathrm{BO}_{3}$, $0.1 \mathrm{~g} \mathrm{Na}_{2} \mathrm{MoO}_{4} \cdot 2 \mathrm{H}_{2} \mathrm{O}, 0.1 \mathrm{~g} \mathrm{NiCl} \cdot 6 \mathrm{H}_{2} \mathrm{O}, 50 \mathrm{mg}$ 
$\mathrm{Na}_{2} \mathrm{SeO}_{3}$ and $51.3 \mathrm{~mL}$ of $37 \% \mathrm{HCl}$ ) was added. Modified A1 medium plates containing either $20 \mathrm{mM}$ of sodium sulfate or the alternate electron acceptor 2,6-anthraquinon-disulphonate (AQDS) were also prepared. Sterile circular pieces of Whatman $3 \mathrm{MM}$ filter paper embedded with different carbon sources (prepared at $1 \mathrm{M}$ ) were placed on top of the medium in petri dishes over the $D$. vulgaris inoculum. These plates were incubated at $30^{\circ} \mathrm{C}$, in anaerobic jars, under two distinct atmospheres (nitrogen or a hydrogen/nitrogen mixture $\left(2.5 \% \mathrm{H}_{2} / 97.5 \% \mathrm{~N}_{2}\right)$ ). Colonies with whitegray coloration were growing next to the filters (see "Results and discussion" section) and were collected with a sterile pipette tip. Afterwards they were suspended in microfuge tubes with $500 \mu \mathrm{L}$ of anaerobic PBS buffer.

Tip-collected colonies were grown in Postdate's medium $\mathrm{C}$ [11], which contained per liter: $0.5 \mathrm{~g}$ $\mathrm{KH}_{2} \mathrm{PO}_{4}, 1 \mathrm{~g} \mathrm{NH}_{4} \mathrm{Cl}, 4.5 \mathrm{~g} \mathrm{Na}_{2} \mathrm{SO}_{4}, 0.06 \mathrm{~g} \mathrm{CaCl}_{2} \cdot 6 \mathrm{H}_{2} \mathrm{O}$, $0.06 \mathrm{~g} \mathrm{MgSO}_{4} \cdot 7 \mathrm{H}_{2} \mathrm{O}, 6 \mathrm{~g}$ sodium lactate, $1 \mathrm{~g}$ yeast extract, $0.004 \mathrm{~g} \mathrm{FeSO}_{4} \cdot 7 \mathrm{H}_{2} \mathrm{O}$ and $0.3 \mathrm{~g}$ sodium citrate $2 \mathrm{H}_{2} \mathrm{O}$. The $\mathrm{pH}$ was adjusted to 7.5 .

PCR amplification and analysis. The extracted DNA [14] was used as a template for a PCR amplification of the 16S rRNA gene sequences. The PCR products were analyzed by Denaturing Gradient Gel Electrophoresis (DGGE) [15]. PCR reactions were carried out in a total volume of $25 \mu \mathrm{L}$ containing $3 \mu \mathrm{L}$ of the above suspensions (previously heated for about $5 \mathrm{~min}$ at $95^{\circ} \mathrm{C}$ for cell lysis), $1 \times$ PCR buffer (TaKaRa Bio. Inc.), $200 \mu \mathrm{M}$ dNTPs, $1 \mu \mathrm{M}$ of each primer 341FGC and 518R [15] and 0.125 $\mu \mathrm{L}$ of Ex Tag (TaKaRa Bio. Inc.) $\left(5 \mathrm{U} \mathrm{L}^{-1}\right)$. The PCR cycling reactions included an initial denaturation step at $95^{\circ} \mathrm{C}$ for $2 \mathrm{~min}$, followed by 35 cycles at $95^{\circ} \mathrm{C}$ for $20 \mathrm{~s}$, annealing at $55^{\circ} \mathrm{C}$ for $20 \mathrm{~s}$, extension at $72^{\circ} \mathrm{C}$ for $40 \mathrm{~s}$. The last cycle was followed by $10 \mathrm{~min}$ at $72^{\circ} \mathrm{C}$. Bacterial $16 \mathrm{~S}$ rRNA gene fragments from known strains were used as migration markers for gel comparison: Escherichia coli K12 (CECT 433), Paenibacillus sp. DSM 34 and Streptomyces caviscabies ATCC 21619. Relative quantification of DNA band intensity after DGGE analysis was carried out as previously described [14].

\section{RESULTS AND DISCUSSION}

In the growth experiments, no colonies were observed next to the filters containing mannose or glucose, but colonies presenting a white-gray coloration were found next to filters with fructose, arabinose and xylose. Growth was also observed for mannitol and myo-inositol. DGGE analysis (Fig. 1) showed additional bands to the ones corresponding to Desulfovibrio vulgaris Hildenborough indicating that those colonies were formed by cells of different microorganisms, and therefore that white-gray colonies contained contaminant microorganisms, which were growing during the incubation procedure. Recovery of the bands followed by sequencing allowed the identification of the microorganisms developing in the cultures: Stenotrophomonas maltophilia (Blast E value $4 \mathrm{e}^{-69}$ ) and Microbacterium sp. (Blast E-value $\left.3 \mathrm{e}^{-56}\right)$. Suspensions of the colonies were observed under a phase-contrast microscope. Desulfovibrio motile cells were observed and many cells were larger than the ones observed in lactate/sulfate cultures. Slightly curved and straight motile rods were also present. One hundred microliters of suspensions of tip-collected colonies grown under a nitrogen atmosphere on medium lacking the addition of sulfate were re-inoculated in a lactate/sulfate Postgate's medium C [11]. As shown in the DGGE analyses of Fig. 2, D. vulgaris cells outcompete the cocultured microorganism during growth in medium containing lactate and sulfate, showing sulfate reduction during its growth in this medium.

Albeit dependent carbohydrate growth of $D$. vulgaris Hildenborough has never been reported, the D. vulgaris Miyazaki F strain, similar in physiology to the Hildenborough strain, can show poor growth on glucose [16]. We were not able to reproduce such results with $D$. vulgaris Hildenborough strain, either with glucose or mannose. However, here it is shown that both S. maltophilia and Microbacterium interact with $D$. vulgaris Hildenborough allowing the sulfatereducer to proliferate in a medium with carbohydrates where it is unable to grow by itself. Both microorganisms found in coculture with Desulfovibrio have been isolated from both clinical and environmental sources, noteworthy $S$. maltophilia, is known to be a plant-root associated bacterium $[17,18]$, often being a dominant member of the rhizosphere microbial community [19]. Microbacterium rhizosphere isolates have also been reported $[20,21]$. The reported utilization of carbon sources by Microbacterium sp. and S. maltophilia is heterogeneous, for instance, growth on fructose or mannose is only possible for some $S$. maltophilia strains and most strains are unable to use arabinose [18, 22]. The type strain $S$. maltophilia $\mathrm{LMG} 958^{\mathrm{T}}$ is unable to utilize arabinose and xylose [23].

Both S. maltophilia and Microbacterium are aerobic bacteria. However, persistence under suboxic or anox-

Fig. 1. DGGE fingerprints of $D$. vulgaris and a cocultivated bacterial species in the presence of different sugars, presence and absence of sulfate or AQDS, and exposed to an atmosphere of nitrogen or a nitrogen/hydrogen mixture. The migration of $D$. vulgaris Hildenborough is shown $(D v)$. The migration of $S$. maltophilia $(\mathrm{Sm})$ (a) and (b) and Microbacterium sp. (Msp) (b) is also indicated. Supplemented sugars are labeled as follows; in panel (a): Fr, fructose; Ar, arabinose; My, myoinositol; and in panel (b): Xy, xylose; Ma, mannitol. A negative amplification control is shown $(-\mathrm{C})$. Migration markers are indicated on the left: Ec, Escherichia coli; $P$, Paenibacillus sp.; Sc, Streptomyces caviscabies. 


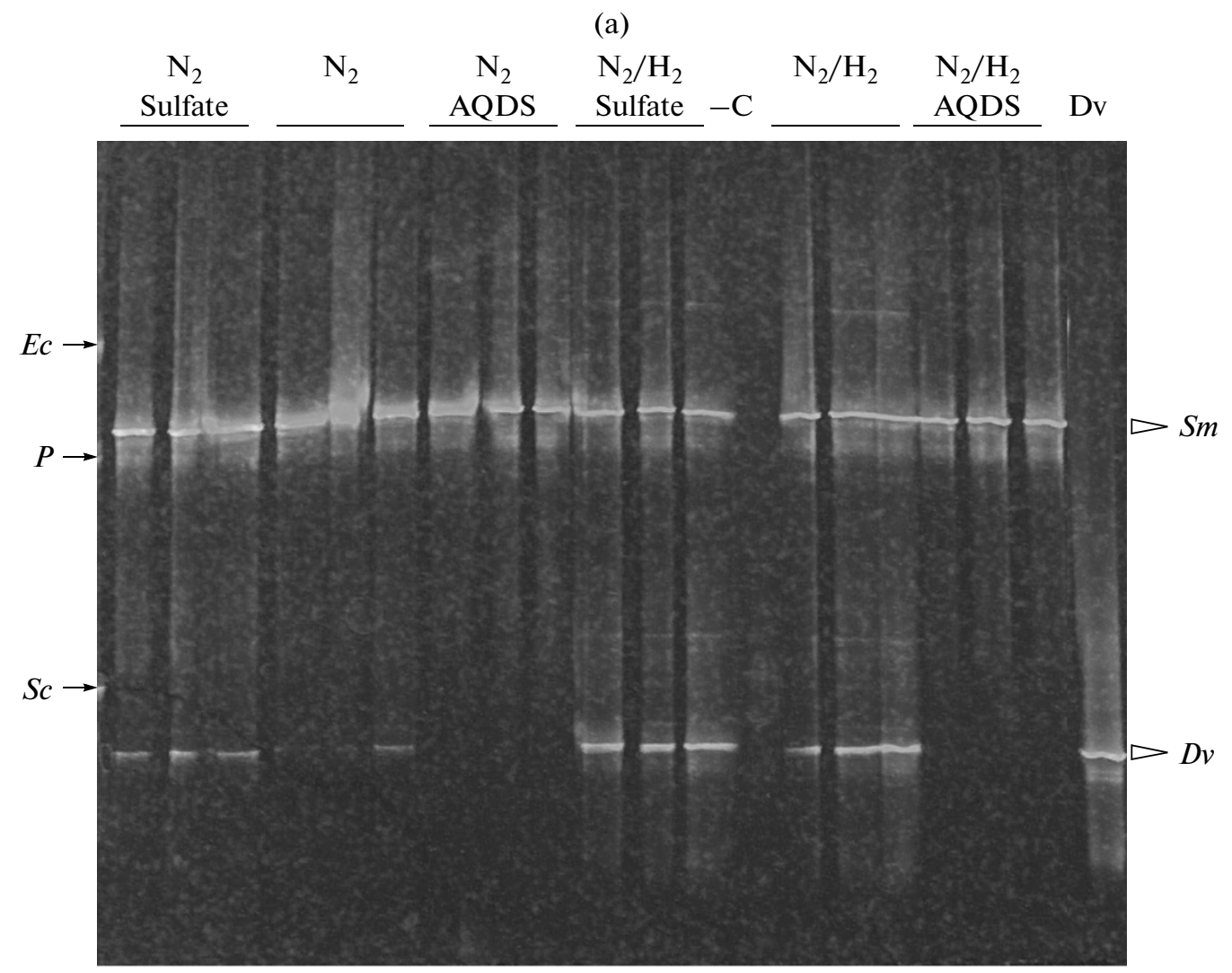

Fr Ar My $\quad$ Fr Ar My Fr Ar My Fr $\operatorname{Ar}$ My $\quad$ Fr Ar My Fr Ar My

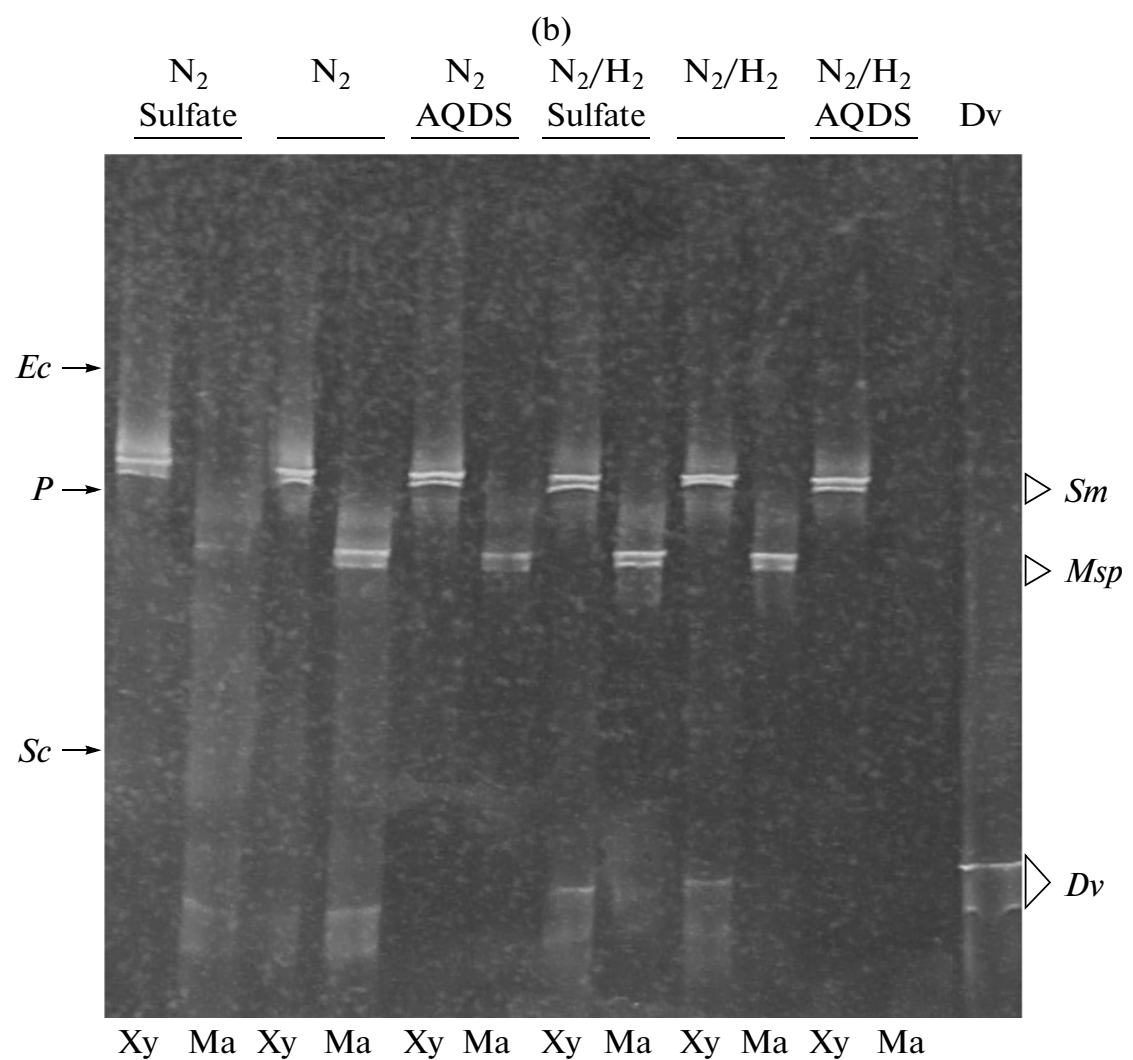




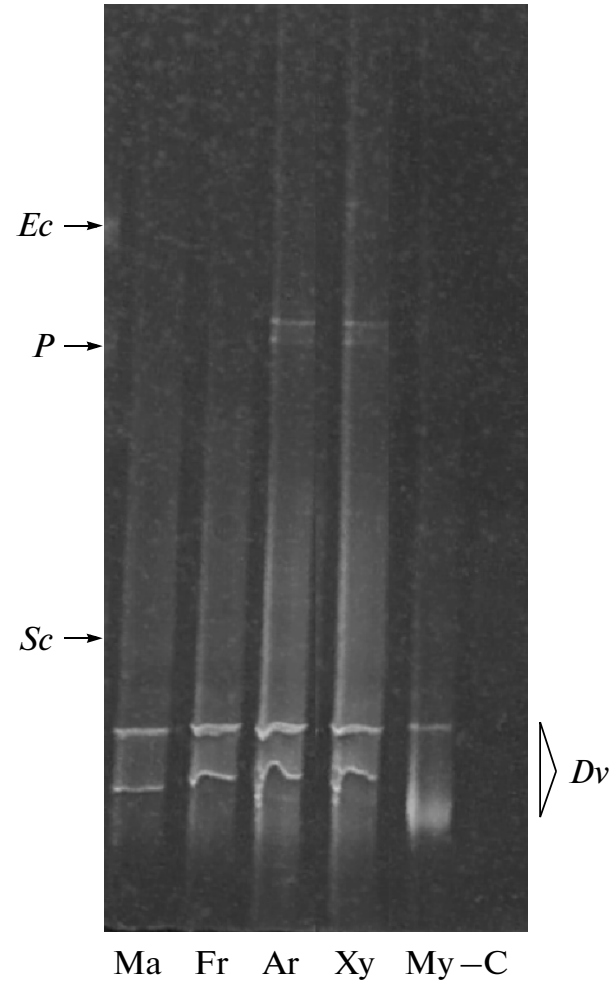

Fig. 2. DGGE fingerprints performed from cultures in Postgate medium C. The inocula of these cultures were colonies previously grown under a nitrogen atmosphere, on different carbon sources and lacking sulfate. The letters at the bottom of the figure indicate the carbon source supplementing the medium where the inoculum was grown: Ma, mannitol; Fr, fructose; Ar, arabinose; Xy, xylose; My, myoinositol. The migration of $D$. vulgaris Hildenborough is shown $(D v)$. A negative amplification control is shown $(-\mathrm{C})$. Migration markers are similar to those indicated on Fig. 1.

ic conditions has been reported for Microbacterium spp. [24]. S. maltophilia is a non-fermentative aerobic bacteria and a potential for growth under microaerophilic conditions has been previously mentioned [25]. Trace amounts of oxygen could be present in our assays, despite anaerobic indicators used denoted the existence of an anoxic atmosphere throughout the experiment. Interestingly, the anaerobic bacterium D. vulgaris Hildenborough contains two membranebound oxygen reductases, a quinol oxidase $b d$ and a cytochrome $c$ oxidase $[9,26]$. Moreover, D. vulgaris Hildenborough can show aerobic respiratory activity comparable to aerobic microorganisms [13 and related references within]. The interactions between the preferentially aerobic growth of a cocultured bacterium and the oxygen respiration survival strategy mechanism of the sulfate-reducer have probably resulted in adequate feedback mechanisms allowing $D$. vulgaris proliferation on carbohydrates. The growth of Desulfovibrio observed in coculrure with $S$. maltophilia or Microbacterium might have been the consequence of the production of one or more metabolites which were used by Desulfovibrio. A $S$. maltophilia strain growing on the aforementioned plates could produce pyruvate and acetate to be used by $D$. vulgaris, as inferred from the metabolic pathways noted for several strains of $S$. maltophilia in the Kyoto Encyclopedia of Genes and Genomes. For instance, strain Hildenborough could grow under $\mathrm{N}_{2}$ atmosphere in the absence of sulfate due to fermentation of pyruvate.

Our results suggest a role for hydrogen in the mutualistic associations with $D$. vulgaris Hildenborough; relative quantitative analysis by DGGE of the experimental communities forming colonies on media supplemented with specific sugars (except in the case of mannitol) showed a higher percentage of $D$. vulgaris cells in the presence than in the absence of hydrogen (Fig. 3). Considering the ability of $D$. vulgaris to grown on hydrogen, it is possible that the use of metabolites produced by the co-cultured bacteria is incremented. Hydrogen uptake could also be associated with the increase of a proton motive force and a proton symport of several metabolites or primary substrate, such as the one previously described for myo-inositol [27]. At this respect, we have observed proliferation of $D$. vulgaris on maltose only when sulfate and hydrogen were present.

An inhibitory effect of AQDS on D. vulgaris Hildenborough has been observed because growth remained undetected and no band through DGGE analysis was observed in the media supplemented with ADQS (see Figs, la and b). Shyu et al. [28] have provided evidence that AQDS enters Shewanella oneidensis and causes cell dead if it accumulates past a critical concentration. A similar effect could also explain the inhibition of $D$. vulgaris Hildenborough by ADQS during this study.

In conclusion, we have identified two microorganisms allowing cell growth of $D$. vulgaris strain Hildenborough in the presence of several carbon sources which are substrates that can not be utilized by this sulfate-reducer. Further experiments are required to understand the nature of these mutualistic associations and the implications for the metabolism and microbial interactions of these bacterial species. Nevertheless, the presented results can explain the growth of the sulfate-reducer $D$. vulgaris in complex systems with abundant organic matter where sulfate-reducing bacteria usually play a critical role in the decomposition of organic compounds. Beyond their obvious function in the sulfur cycle, sulfate-reducing bacteria play an important role in global cycling of elements [29]. For example, in the carbon cycle, the sulfate-reducing bacteria have been hypothesized to form part of microbial consortia that completely mineralize organic carbon in anaerobic environments; polymeric materials (e.g., cellulose) should be first depolymerized and then metabolized by fermentative microorganisms [30, 31]. Previous studies have reported that $D$. vulgaris uses lactate, pyruvate, ethanol, malate, and fumarate, but 
(a)
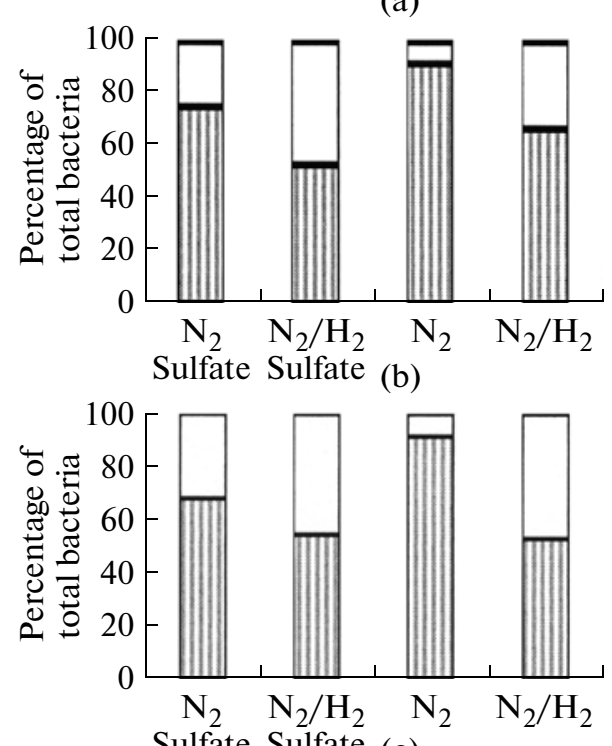

Sulfate Sulfate (c)

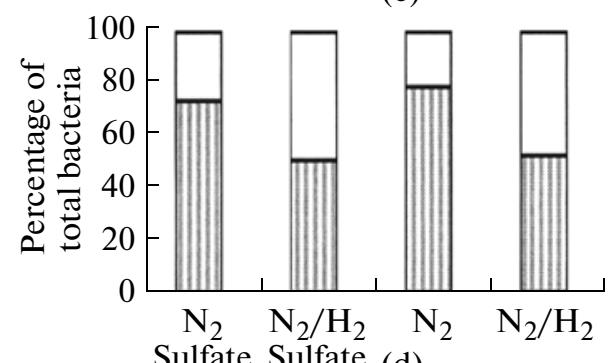

Sulfate Sulfate (d)

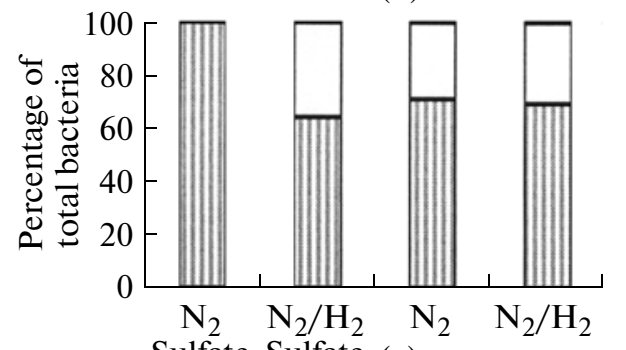

Sulfate Sulfate (e)

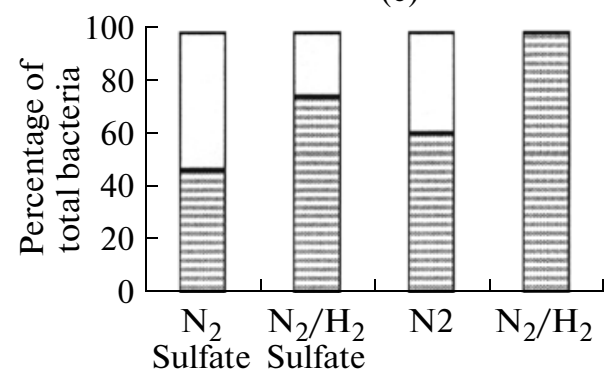

Fig. 3. Results of relative quantitative DGGE analysis of band intensity obtained from cultures of $D$. vulgaris and a cocultivated bacterial species in the presence of different sugars, presence and absence of sulfate, and under an atmosphere of nitrogen or a nitrogen/hydrogen mixture. The fractions represented by $D$. vulgaris Hildeborough (white portions) and $S$. maltophilia (portions with vertical lines) and Microbacterium sp. (portions with horizontal lines) are shown. The results obtained for growth on different sugars are presented: (a), fructose; (b), arabinose; (c), myoinositol; (d), xylose; (e), mannitol. not sugars [9, 32]. The evidence shown in this study corroborates the role of sulfate-reducing bacteria, in particular of $D$. vulgaris Hildenborough, in microbial mineralization and degradation processes of organic matter and carbon cycling in nature through interactions with other heterotrophic bacteria.

\section{ACKNOWLEDGMENTS}

Margarida Santana was recipient of a grant (SFRH/BPD/34404/2006) from "Fundação para a Ciência e a Tecnologia". The authors acknowledge funding from the Government of Andalusia (BIO288) and the Spanish Ministry of Science and Innovation (CGL2009-12328).

\section{REFERENCES}

1. Postgate, J.R. and Campbell, L.L., Classification of Desulfovibrio Species, the Nonsporulating Sulfate-Reducing Bacteria, Bacteriol. Rev., 1966, vol. 30, pp. 732738.

2. PanKhania, LP., Gow L.A., and Hamilton, W.A., The Effect of Hydrogen on the Growth of Desulfovibrio vulgaris (Hildenborough) on Lactate, J. Gen. Microbiol., 1986, vol. 132, pp. 3349-3356.

3. Voordouw, G., Carbon Monoxide Cycling by Desulfovibrio vulgaris Hildenborough, J. Bacteriol., 2002, vol. 184, pp. 5903-5911.

4. Tang, Y., Pingitore, F., Mukhopadhyay, A., Phan, R., Hazen, T.C., and Keasling, J.D., Pathway Confirmation and Flux Analysis of Central Metabolic Pathways in Desulfovibrio vulgaris Hildenborough Using Gas Chromatography-Mass Spectrometry and Fourier Transform-Ion Cyclotron Resonance Mass Spectrometry, J. Bacteriol., 2007, vol. 189, pp. 940-949.

5. Pfennig, N., Metabolic Diversity among the Dissimilatory Sulfate-Reducing Bacteria, Antonie van Leeuwenhoek, 1989, vol. 56, pp. 127-138.

6. Ollivier, B., Cord-Ruwisch, R., Hatchikian, E.C., and Garcia J.L., Characterization of Desulfovibrio fructosovorans, Arch. Microbiol., 1988, vol. 149, pp. 447-450.

7. Nielsen J.T., Liesack, W., and Finster K., Desulfovibrio zosterae sp. nov., a New Sulfate-Reducer Isolated from Surface-Sterilized Roots of the Seagrass Zostera marina, Int. J. Syst. Bacteriol., 1999, vol. 49, pp. 859-865.

8. Sass, H. and Cypionka, H, Isolation of Sulfate-Reducing Bacteria from the Terrestrial Deep Subsurface and Description of Desulfovibrio cavernae sp. nov., Syst. Appl. Microbiol., 2004, vol. 27, pp. 541-548.

9. Heidelberg, J.F., Seshadri, R., Haveman, S.A., Hemme, C.L., et al., The Genome Sequence of the Anaerobic, Sulfate-Reducing Bacterium Desulfovibrio vulgaris Hildenborough, Nat. Biotechnol., 2004, vol. 22, pp. 554-559.

10. Santana, M. and Mednansky M.-C., The Adaptive Genome of Desulfovibrio vulgaris Hildenborough, FEMS Microbiol. Lett., 2006, vol. 260, pp. 127-133.

11. Postgate, J.R., The Sulfate-Reducing Bacteria, 2nd ed., Cambridge University Press, Cambridge, UK, 1984. 
12. Weller, D.M. and Thomashow, L.S., Current Challenges in Introducing Beneficial Microorganisms into the Rhizosphere, Molecular Ecology of Rhizosphere Microorganisms, O'Gara, F., Dowling, D.N., and Boesten, B., Eds., VCH, New York, NY. 1994, pp. 1-18.

13. Santana, M., Presence and Expression of Terminal Oxygen Reductases in Strictly Anaerobic Sulfate-Reducing Bacteria Isolated from Salt-Marsh Sediments, Anaerobe, 2008, vol. 14, pp. 145-156.

14. Portillo, M.C. and Gonzalez, J.M., Statistical Differences between Relative Quantitative Molecular Fingerprints from Microbial Communities, Antonie van Leeuwenhoek, 2008, vol. 94, pp. 157-163.

15. Muyzer, G., de Waal, E.C., and Uitterlinden, A.G., Profiling of Complex Microbial Populations by Denaturing Gradient Gel Electrophoresis Analysis of Polymerase Chain Reaction-Amplified Genes Coding for 16S rRNA, Appl. Environ. Microbiol., 1993, vol. 59, pp. 695-700.

16. Kitamura, M., Takayama, Y., Kojima, S., Kohno, K., Ogata, H., Higuchi, Y., and Inoue, H., Cloning and Expression of the Enolase Gene from Desulfovibrio vulgaris (Miyazaki F), Biochim. Biophys. Acta, 2004, vol. 20, pp. 172-181.

17. Debette, J. and Blondeau, R., Présence de Pseudomonas maltophilia Dans la Rhizosphère de Quelques Plantes Cultivées, Can. J. Microbiol., 1980, vol. 26, pp. 460463.

18. Berg, G., Roskot, N., and Smalla, K., Genotypic and Phenotypic Relationships between Cinical and Environmental Isolates of Stenotrophomonas maltophilia, J. Clin. Microbiol., 1999, vol. 37, pp. 3594-3600.

19. Juhnke, M.E. and Des Jardin, E., Selective Medium for Isolation of Xanthomonas maltophilia from Soil and Rhizosphere Environments, Appl. Environ. Microbiol., 1989, vol. 155, pp. 747-750.

20. Soltmann, U., Wand, H., Müller, A., Kuschk, P., and Stottmeister, U., Exposure to Xenobiotics Deeply Affects the Bacteriocenosis in the Rhizosphere of Helophytes, Acta Biotechnol., 2002, vol. 22, pp. 161-166.

21. Child, R., Miller, C.D., Liang, Y., Narasimham, G., Chatterton, J., Harrison, P., Sims, R.C., Britt, D., and Anderson, A.J., Polycyclic Aromatic HydrocarbonDegrading Mycobacterium Isolates: Their Association with Plant Roots, Appl. Microbiol. Biotechnol., 2007, vol. 75, pp. 655-663.

22. Denton, M. and Kerr, K.G., Microbiological and Clinical Aspects of Infection Associated with Stenotroph- omonas maltophilia, Clin. Microbiol. Rev., 1998, vol. 11, pp. 57-80.

23. Kaparullina, E., Doronina, N., Chistyakova, T., and Trotsenko, Y., Stenotrophomonas chelatiphaga sp. nov., a New Aerobic EDTA-Degrading Bacterium. Syst. Appl. Microbiol., 2009, vol. 32, pp. 157-162.

24. O'Toole, R., Smeulders, M.J., Blokpoel, M.C., Kay, E.J., Lougheed, K., and Williams, H.D., A Two-Component Regulator of Universal Stress Protein Expression and Adaptation to Oxygen Starvation in Mycobacterium smegmatis, J. Bacteriol., 2003, vol. 185, pp. 1543-1554.

25. Crossman, L.C., Gould, V.C., Dow J.M., Vernikos, G.S., et al., The Complete Genome, Comparative and Functional Analysis of Stenotrophomonas maltophilia Reveals an Organism Heavily Shielded by Drug Resistance Determinants, Genome Biol., 2008, 9, R74, doi: 1186/gb2008-9-4-r74

26. Lamrabet, O., Pieulle, L., Aubert, C., Mouhamar, F., Stocker, P., Dolla, A., and Brasseur, G., Oxygen Reduction in the Strict Anaerobe Desulfovibrio vulgaris Hildenborough: Characterization of Two MembraneBound Oxygen Reductases, Microbiol., 2011, doi: 10.1099/mic.0.049171-0

27. Deshusses, J.P.M., Myo-Inositol Transport in Bacteria: $\mathrm{H}^{+}$Symport and Periplasmic Binding Protein Dependence, Annals NY Acad. Sci., 1985, vol. 456, pp. 351360.

28. Shyu, J.B.H., Lies, D.P., and Newman, D.K., Protective Role of tolC in Efflux of the Electron Shuttle Anthraquinone-2,6-Disulfonate, J. Bacteriol., 2002, vol. 184, pp. 1806-1810.

29. Trüper, H.G., Microorganisms and the Sulfur Cycle, Sulfur: Its Significance for Chemistry, for the Geo-, Bio- and Cosmosphere, and Technology, 5th ed., Müller, A. and Krebs, B., Eds., Elsevier, Amsterdam, 1984, pp. 351365.

30. Mann, K.H., Production and Use of Detritus in Various Freshwater, Estuarine, and Coastal Marine Ecosystems, Limnol. Oceanogr., 1988, vol. 33, pp. 910-930.

31. Skyring, G.W., Acetate as the Main Energy Substrate for the Sulfate-Reducing Bacteria in Lake Eliza (South Australia) Hypersaline Sediments, FEMS Microbiol. Ecol., 1988, vol. 53, pp. 87-94.

32. Widdel, F. and Bak, F., Gram-Negative Mesophilic Sulfate-Reducing Bacteria, The Prokaryotes. Balows, A., Trüper, H.G., Dworkin, M. and Schleifer, K.-H., Eds., New York, Springer-Verlag, 1992, pp. 3352-3378. 